\title{
DR. ARCHIBALD CAMERON
}

by

\author{
LORD AMULREE
}

AMONG THE lives of the many men and women who have been qualified to practise the art of medicine are a number who have moved from that discipline into others where they have made a name and reputation for themselves which they might not have attained to had they remained loyal to their first choice: yet they have brought to their other work something which they learned in the days when their first choice was still their main strength. There are others who, because their lives became involved in the march of events, in a way which they never could have suspected, have acquired a fame and a historical importance which has nothing to do with their innate involvement of their skill in their chosen profession. Among these can be cited Archibald Cameron. Until the age of thirty-eight he was, as far as one can tell, a hard-working and successful practitioner in Lochaber. In 1745 he was caught up in the whirlwind of the Jacobite rebellion and until his execution eight years later worked as a professional soldier, moved in a minor way in politics and was an active agent in the Jacobite cause: for this latter he has the unenviable reputation of being the last person to suffer execution for loyalty to the House of Stuart. It may be asked, with some justification, whether such a man has any place in medical history: the answer must be, surely, that he has. Medicine is one of the oldest arts practised in the world today: it has been enriched and fertilized by the personalities of its many practitioners. Archibald Cameron may not have been a very great doctor, he certainly contributed nothing to the advances of medical knowledge. Yet by his courage and loyalty he has set an example which many could with benefit follow and for this he is entitled to a place among that great number of doctors who have contributed, by their example, something which is of value to the whole structure of medical practice in the world today.

Archibald Cameron was born in 1707, the fourth son of John Cameron, chief of the clan Cameron. The Camerons were a large clan with extensive lands in the west of Scotland, their chief was known as the Laird of Lochiel whose family home was at Achnacarry, near the eastern end of Loch Arkaig. The Camerons were described as 'a very potent clan in Lochaber-the Laird of Lochiel is their chief, who . . . has a good competent estate. ... He can bring out 800 men.' John Cameron was living in exile in Paris for his share in the Jacobite rebellion of 1715.

Archibald, we may presume, was brought up at Achnacarry, but the records of his early days are meagre. At some stage in his life he decided to become a doctor: although this may seem to be unusual for the son of a powerful, though exiled, Highland chief, yet it was not uncommon for the younger sons of Highland gentry at that time to enter the medical profession: a frequent alternative was the profession of innkeeper, some, in fact, combined the two. After Cameron's death, a short 


\title{
Dr. Archibald Cameron
}

biography of him was written by Alexander Henderson in which a few details of his education were given. As a boy, he had been taught at the local school at Inverness by Mr. Alexander Macbaine, who is said to have been an 'honest man'. Here he learnt, and became proficient in, Latin and Greek, in which subjects Macbaine appears to have been a good scholar. After leaving this school he went to the College in Glasgow, where he studied Latin under Mr. Andrew Ross, 'a man of great knowledge of the Latin tongue, being a person of a quick turn of mind, but without any solid judgement' and Greek under Mr. Dunlop 'the gentleman who has obliged the world with a better grammar than any extant.' He also studied Moral Philosophy under Mr. Francis Hutchinson, 'an Irish gentleman, who has wrote so elegantly on the Passions and Moral Virtue' and Mathematics under Mr. Robert Simpson, 'who has wrote a most elaborate and excellent treatise on Conic Sections'. In his spare time he attended classes in Divinity under Mr. John Simpson, the Professor of Theology. At this time, according to Henderson, Cameron intended to study for the Scottish Bar, but when he discovered that 'in order to be properly qualified for an advocate he must be master of all the quirks and sophistical reasonings, that are usually made use of to puzzle a cause and to hoodwink the understanding with factitious arguments', he abandoned that project and decided to devote his time to the study of medicine.

It must have been about this time that his eldest brother, Donald, wrote to his cousin, Macgregor of Balhaldy:

\begin{abstract}
My brother Archie has capacity enough but no application, he learned his Logic, but I am afraid to little purpose, he has made no great advance in his Greek or Latin, and it will be to no purpose to send him [letter torn] especially since his brother can't continue with him, He's inclined to be a doctor, which, you know, without being master of Greek or Latin he cannot propose to follow, besides the vast expence I must be at, which my circumstances cannot bear, so that, in my opinion, to bind him prentice to an able surgeon is the best way to dispose of him, and what little stock he has himself, with a little addition, may pay his prentice fee.
\end{abstract}

In a list of students who studied medicine in Edinburgh Cameron is recorded as a pupil of John Blair, a Fellow of the Royal College of Surgeons of Edinburgh, in 1723 , for which year he paid an honorarium of three guineas; again, in a list dated 18 October 1727, he paid another three guineas to the same John Blair; while in a third list, dated 12 January 1728, he paid one guinea, once again to John Blair. In Henderson's life, however, he says that Cameron also worked under Dr. Alexander Monro, the great anatomist, and that he studied physic under Dr. Sinclair, who is probably better known as St. Clair. It is said, too, that Cameron after leaving Edinburgh studied for one year on the continent, and it is possible that he followed Monro to Leyden as a pupil of Boerhaave, although some writers, although they produce no evidence for this statement, say that he spent a year in Paris. After his stay abroad Cameron returned to his native Lochaber and began to practise medicine among his brother's clansmen. Shortly after his return, probably between 1732 and 1733, Cameron married his cousin, Jean Cameron of Dungallon, by whom he had at least eight children, the last of whom was born after his death.

Cameron and his brother Donald, the acting chief of the clan, both had the prosperity and wellbeing of their clansmen at heart and worked hard to improve 


\section{Lord Amulree}

conditions in their part of the country, and, helped by a 'genteel behaviour and by countenancing honesty and industry' succeeding in producing a degree of improvement. Few details of his life at this time have survived, but there are references to the assistance given by both Cameron and his brother to General Wade in his road building and how they laid: "the strictest commands on the whole of their men, to be obliging to the soldiers, and do everything in their power to rendering the situation agreeable so that whatever misrepresentations Mr. Wade might give of Scotland, he had no occasion to complain.' Again, Cameron, it seems, encouraged the clansmen to work in the lead mines of Strontian, in Cameron country, where: 'he made it his business to oblige all concerned, and both by his advice and example was the happy instrument of civilising his people in those remote parts giving them a relish for trade and commerce and encouraging them to gain their bread by laudable industry and working in the mines.' From two letters which Cameron wrote to his cousin, Balhaldy, in 1732 and 1733, it seems that Cameron was not only engaged in looking after the health of the lead miners at Strontian but that he also acted as agent for members of his family in certain financial matters connected with these mines.

But this pleasant and useful state of affairs was not to last, for in 1740 a number of the leading Jacobites in Scotland formed themselves into an 'Association' to watch the European political situation and at the same time a young man, John Murray of Broughton, became correspondent to the Jacobite court in Rome, while two other young Jacobites, Macgregor of Balhaldy and Francis Sempill, kept watch over events in France. The war of the Austrian succession broke out in 1742 with France and England fighting on opposite sides, although technically not at war with each other, and after the indecisive battle of Dettingen in June 1743, Amelot, the French foreign minister, thought that a diversion on the flank might be useful, and was assured by Jacobite agents, notably Balhaldy, that the royal family were very unpopular in England and that many members of Parliament and the City of London generally were secretly in sympathy with the Stuart King James and that a landing in England would be followed by an immediate and successful rising. After a certain amount of delay Prince Charles Edward sailed from Belleisle, in France, on 4 July 1745, on board a French brig, the Du Tellay. On 25 July the Prince landed at Borradale, on Loch-nan-uagh, with seven men, 4,000 Louis d'ors, 1,000 muskets and 1,800 broadswords. He summoned Lochiel to visit him immediately, but he, fearing that a personal interview with the Prince might lead to a weakening of his conviction that the whole enterprise must be immediately abandoned, sent his brother, Archibald, to urge the Prince to return at once to France. Cameron arrived on the same day and Sir John Macdonald, one of the seven men, records: 'Doctor Cameron came also, talked a lot and promised nothing, except that if he joined the Prince's Standard he would be among the last to quit it, a promise which was well and truly kept.'

The Prince refused to abandon his project and Lochiel himself visited him, but was soon persuaded to support the Prince and returned home to tell his family and the rest of the clan. But: 'they were amazed at the matter, opposed his setting up his standard, and none was more strenuous against him than the unfortunate gentleman, the Doctor, who even proposed to confine his brother that he should not venture upon such a scheme, that might bring certain ruin upon those concerned in it.' Lochiel, 


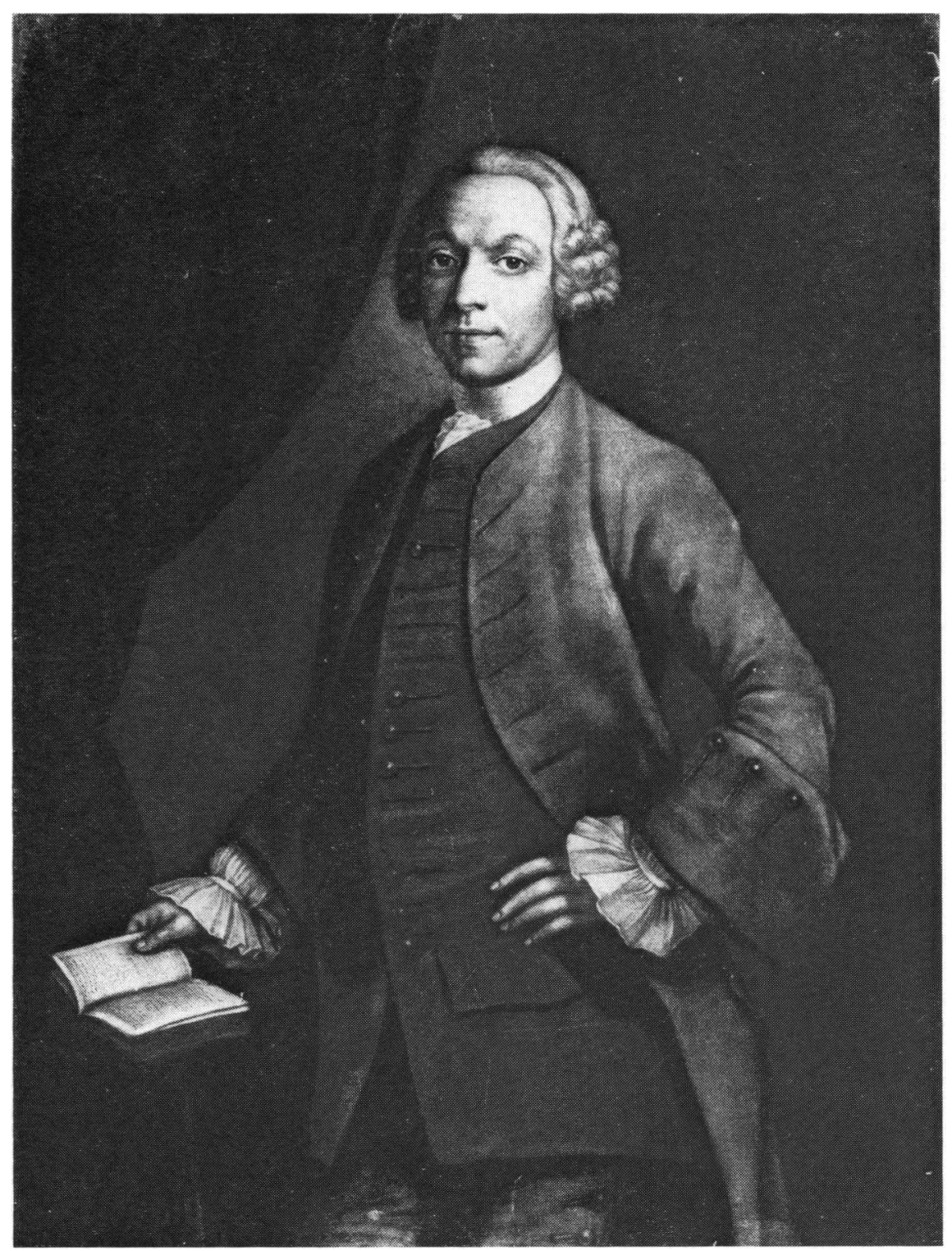

Archibald Cameron (1707-1753). (From a print in the British Museum, artist unknown). 


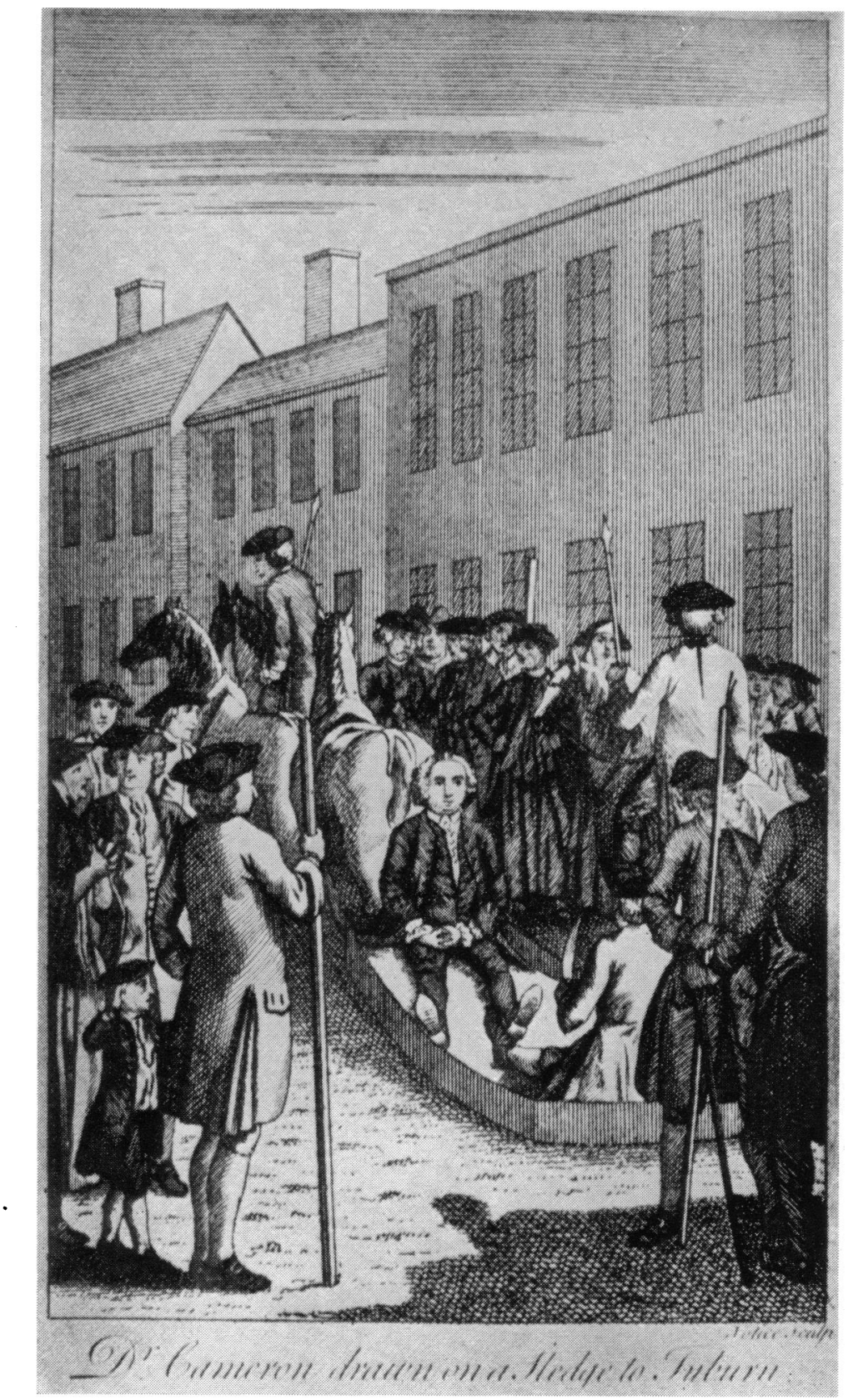

Drawing to Tyburn on a sledge, 1753. 


\section{Dr. Archibald Cameron}

however, had made up his mind to support the Prince and appointed a rendezvous for the clan. Cameron decided not to appear, whereupon Lochiel: 'sent a party for him, and by the ties of a brother, the obligations due to a benefactor and a chieftain, he commanded his assistance. The Doctor withstood the most earnest solicitations for a time; till, by the persuasion of Lochiel's lady . . . his mind was somewhat reconciled to the project; he loved his brother Lochiel, who was his only support, and forced him out under pain of his highest displeasure; even threatening to pistol him if he did not comply; and insisted that it was the least thing he could do to attend his person, and cure him of any hurt he might receive.'

Once he had agreed to come out with the clan, Cameron was active in encouraging others to follow him. There is a statement from John Cameron, when a prisoner, in which he declares that Dr. Cameron came to Cameron of Dungallon: 'and forcibly brought from thence five hundred men, mostly of the name of Cameron, threatening them that if they did not come off directly he would burn their houses and cut them in pieces'; while another member of the same clan stated that: 'Dr. Cameron killed four of his cows before he consented to go with him'.

There is some doubt of the position that Cameron held in the Jacobite army: he himself said that: "he had the honour to serve his ever dear master in quality of one of his aides de camp, while Henderson says that he had no commission in the rebel army, being no more than a physician attending his brother, and to be ready at hand in case any accident might happen to him. But, as will be shown, he did take an active part in military operations, and two witnesses who gave evidence against him in 1746 said that during the whole rebellion he acted as A.D.C. to the Pretender. There were at least twenty-five other doctors in the Jacobite army, of whom one, at least, seems to have acted as a combatant.

References to Cameron's activities during the rebellion are not many, but on 29 August 1745, he was sent with a party of about sixty Camerons to occupy the barracks at Ruthven, but this adventure was not successful on account of the gallant defence put up by the Government troops. Henderson says that Cameron was instrumental in checking any promiscuous slaughter of prisoners after the battle of Preston Pans and records that he treated a captain in the Hanoverian army who had lost a hand. Cameron of Kinloch, who caused the wound, 'scraped together some crushed earth off the field, which he put on his handkerchief, applied it to the gentleman's stump, stopped the bleeding, and then introduced him to Dr. Cameron, who in the most tender and sympathetic manner dressed his wound, as he did of several other prisoners.'

At Kendal, again, on the retreat from Derby;

where on December 15th, some people at a market began to mob a party of Hussars, then marching with Perth, a nobleman universally beloved through the army; as the main body came up and were informed of it, they breathed nothing but revenge, threatening to burn the town about their ears, unless ransomed by the sum of twenty thousand pounds; the Magistrates knew not what to do, to pay the sum was out of their power; at last one of them addressed Dr. Cameron, and told him that none of the town's people were concerned in the riot, that the matter happened on a public market-day, wherein offenders could not so easily be distinguished: the Doctor greatly sympathised with his case, acknowledged the truth of what he advanced, and instantly promised relief, which was soon procured, for he informed his brother Lochiel of what the alderman had said, and so the contributions were greatly abated. 
In July of this year Cameron later claimed that he and his brother had successfully opposed a proposal to distress the house of Campbell of Invera, presumably because he would not join the rebels, while when the people of Kirkintulloch were in danger of massacre following the killing of two of Lochiel's servants this was averted by the joint action of Cameron and his brother.

At the battle of Falkirk, Lochiel was slightly wounded in the leg and while Cameron was attending him: 'he received a shot in the breast and would have had it through the body if it was not for his target.' He complained in later years: 'especially if the ball received at Falkirk and is still in my body give me as much pain and trouble as it did in winter and spring last which helped the continuance of my sickness at that time.' After the battle of Culloden, Cameron helped his brother, Lochiel, badly wounded in both ankles, off the field and went into hiding-skulking, as it was colloquially called - with other Highlanders.

The remnants of the Jacobite army broke up and scattered, and the Prince left the mainland for the Hebrides on 26 April. Cameron, who had been sent by the group which surrounded the wounded Lochiel, brought back to them this unwelcome news. At the same time, two French ships arrived at Loch-nan-uagh with money and arms for the Prince. Cameron with some difficulty persuaded the French to put the money on shore, some 35,000 Louis d'ors packed in bags in seven casks, and this was buried by Cameron and his friends in the woods round Loch Arkaig. News of the landing of the money soon reached the ears of Government troops who searched, in vain, for it among the woods. They were often: 'round the place where it was and missed narrowly finding it, for being hid by gentlemen not used to work it was very unskillfully done and the stamps and impressions of their feet visible about the place.' However, the money was not discovered and its final distribution was the cause of much jealously and bad feeling among the Jacobites.

An attempt was also made to rally some of the scattered Jacobite troops and a small army assembled near Loch Lochy: this soon found that it was hopelessly outnumbered by Government troops and was disbanded on 23 May. From various items recorded by Murray of Broughton, the treasurer to the whole expedition, it seems that Cameron helped considerably in provisioning and otherwise equipping this small body of troops:

item 8. Mr. M. paid Mrs. Cameron about $\mathbf{f 4 0}$ for part of their cattle in the Doctor's presence, the others he cannot recall to mind being country people.

To cattle brought from Dr. Cameron and others to supply men rendezvoused at Glenmely $£ 90$. item 9. Dr. Cameron was the person Mr. M. chiefly employed to procure their horses and some of these were bought from a tennant of Lochiel's in Glenpayen.

To horses to carry the ammunition to be sent by Mr. MacDonald of Clanranald from the coast of Arisaig to the head of Loch Shiel $\mathbf{f 4 5}$.

The next two or three months were spent by Cameron skulking in various parts of the Highlands with a few friends, and his own house was destroyed by Government troops and his wife and family forced to go into hiding. Later Mrs. Cameron told how when two of her children died during this time she was advised to bury them in some quiet heatherly brae to prevent their bodies from being dug up from the family 


\section{Dr. Archibald Cameron}

burial ground for the sake of their linen shrouds, while another daughter was stripped of all her clothes by Government troops.

On 5 July the Prince returned to the mainland and on 20 August was joined by Cameron and others who moved him to the comparative safety of a: 'very romantic comical habitation made for him by Cluny, at two miles distance into Benalder, called the Cage'. The accommodation in the Cage was limited, for it: 'was no larger than to contain six or seven persons, four of which number was frequently employed in playing at cards, one idle looking on, one baking and another firing bread and cooking'. Cameron stayed at the Cage for a week and then made a journey with Macpherson of Cluny to Lock Arkaig, to show him where the money was buried. On their way back to the Cage they ran into a messenger who was looking for the Prince to tell him that two French ships had arrived in Loch-nan-uagh to take him back to France. The Prince and his party set out for the coast and with Cameron, Lochiel and others embarked on one of the ships, L'Heureux.

The journey to France was uneventful, and the Prince spent some of his time dictating a short account of his adventures in Scotland: this was taken down, in part by Archibald Cameron. On 10 October L'Heureux arrived at Roscoff and the Prince with his party left at once for Paris, where they were warmly received by the Minister and, a few days later, by Louis XV at Fontainbleau. In the middle of November the Prince moved into a rented appartment on the quay in Paris, L'Hotel d'Hollande, where he lived quietly, entertaining only members of his immediate suite, of whom Cameron was one. His brother, the Duke of York, also had an apartment in the same building.

As far as one can make out with his arrival in France, Cameron finished with his life as a practising doctor. The French government were generous to those Jacobite exiles who had served the cause well, and made grants of money to them which were known as 'gratifications'. In a list of these, dated November 1746, 3,000 livres are awarded to Colonel Cameron-one assumes this to have been Archibald-and a further 1,000 livres was paid to Archibald Cameron in January 1747. Cameron recorded later that, because he lived so much with the Prince, he was able to save a considerable amount of his 'gratification' against the time when his wife and family could join him in France. About this time, too, the French government sanctioned the raising of one Scottish regiment in the French army: this was to be called after Lord Ogilvy. Cameron was to be gazetted a Captain in command of the second batallion and his brother, Lochiel, was to be in command. All this is evidence of how well Cameron's loyalty and good sense was appreciated by the Prince and his brother, although we know that at this time Cameron and others were becoming anxious at the extent to which the Prince's thoughts and actions were becoming increasingly influenced by the Irishman, Kelly.

In the spring of 1747 the Prince, disappointed at the apparent lack of support for his future shown by the French government, decided to try his luck at the court of Spain. Accompanied by Cameron and one other he arrived without warning in Madrid and had, after some difficulty, an unsatisfactory and embarrassing interview with the Spanish, King Ferdinand VI and queen and several talks with the Minister, Carvajal: none of these chose to become involved in Jacobite plotting. It was, 


\section{Lord Amulree}

however, agreed that ships with flour, brandy, soap and tobacco should be sent to the Highlands and that Cameron should go ahead of them to Scotland to receive them and to help in the distribution of this relief. There is no further evidence that this relief was ever sent or that Cameron visited Scotland at that time. He was, however-and this further evidence of the esteem in which he was held in Jacobite circles-given the commission of a Colonel in the Spanish army, with no obligation on him either to serve in that army, or, indeed, to live in Spain. With an income derived from his two commissions the prospect for Cameron seemed bright, but the delaying tactics of the Spanish treasury made it unlikely that Cameron ever received anything like the full amount of the money to which he was entitled from his Spanish commission, if, indeed, he ever received anything at all. He remained in Spain until May of 1747, and in August wrote to his wife asking her to come and join him in France. But Mrs. Cameron delayed her departure until January 1748, when she arrived safely at Breda with two out of her four surviving children. Here she was arrested by the English army authorities and was interrogated by the Earl of Albemarle, their commander. He allowed her to continue her journey to France, where she arrived to join her husband in Paris in March of that year.

In October Lochiel, Cameron's elder brother, died and the future of his regiment was at once in question: the French were considering amalgamating it with one of the other, older established, Scottish regiments in their service. Cameron saw difficulties for himself if this were to happen. In the same month the long war of the Austrian Succession was ended by the treaty of Aix-la-Chapelle, one of the terms of this was that the French should no longer allow Prince Charles to live in their country. In spite of all Louis XV's appeals, the Prince obstinately refused to leave France and in December was arrested on his way to the opera, lodged in the château de Vincennes and then deported to Papal territory at Avignon. His immediate household, to the number of about thirty, were removed for a short while to the Bastille, among the archives of which is a letter to Cameron from his uncle, Ludovic Cameron of Torcastle, written on 15 December in which he asks his nephew to collect three shirts and one nightcap for him from his washerwoman and to pay her for her work.

So worried was Cameron about his prospects in both the French and Spanish armies that he wrote to King James, in Rome, asking for his assistance. The Pretender replied that he had little influence with the French in the way they reformed their army, but he did appeal to Cardinal Portocarrero, the Spanish ambassador to the Papal States, for any help he could give in arranging for the regular payments of the money due from Cameron's Spanish commission. This appeal was, however, quite unsuccessful.

In September 1749, Cameron visited Scotland to consult with Macpherson of Cluny on the disposal of the French gold that had been buried on the banks of Loch Arkaig in 1746. There has been a great deal of confusion, disagreement and accusations over the ultimate fate of this gold, and Cameron has been accused, almost certainly unjustly, of having removed about $£ 6,000$ for his own use. The fact that he probably behaved stupidly about this money does not mean that he misappropriated it. He took what he thought he was entitled to to help 'the ruined family of Lochiel' and also some $£ 300$ for his own expenses. His accuser is Macdonell of Glengarry 


\section{Dr. Archibald Cameron}

who later was known to have been a spy in the service of the British Government and whose word must, therefore, be suspect. On hearing of the accusations made against him Cameron immediately left for Rome to put his side of the case to the Pretender, and returned to France satisfied with his reception and that the charges against him were not believed. While on his way to Rome, Cameron did not communicate with his wife who feared that he might have got lost in Marseilles and asked the Jacobites there to keep an eye open for him - they would quickly know him for a foreigner by his not speaking the language'-and this after three years' living in France!

In 1750 Cameron notes that two of his children were still being taken care of by friends or relatives in Scotland and in 1751 another child was born 'who had the honour of being called James after the King'. Cameron himself was ill at the same time 'of a most dangerous fever and ague which confined him all the winter wholly to his room and mostly to his bed, which has shattered his constitution much ever since'. Later in the same year Mrs. Cameron visited Edinburgh again and was arrested in the month of October and interrogated by Charles Erskine of Tinwald, the Lord Justice Clerk, whose duty it then was to act as a political agent of the Crown, in addition to his duty as a senior judge in the Court of Session. Her belongings were searched, but no treasonable material was found among them and it was agreed that she had come over to see friends and relatives on matters 'relating only to the squabbles at their sham court who the persons were who had secreted the money, each of them putting it upon the other'. She left the country shortly after to join her husband who was then stationed at Douai with his regiment.

It was reported that Cameron also visited Scotland during this year, but this is unlikely in view of his own illness and of his wife's visit to Edinburgh in the autumn. In September, however, reports began to come in to the Government from Macdonel of Glengarry, the treacherous Highlander to whom reference has already been made. The Prince was said to have interviewed Cameron at Menin and told him to proceed at once to Scotland, with Lochgarry, with the news that he hoped to land shortly in that country with a force of Swedish troops and with the backing of the King of Prussia, Frederick the Great, who was George II's nephew. The Prince gave money to the two men and told them to meet supporters from the Highlands at the market for black cattle held at Crieff. How much truth there was in this story, we shall never know: but it sounds improbable on the face of it. However, the Government felt bound to take action, and it was soon confirmed to them that the two men were, in fact, in Scotland and reports of conversations that Cameron was supposed to have had with various men in the Highlands during the winter confirmed Glengarry's reports. Erskine himself was doubtful if there was any real basis for alarm, but added in a report to the Duke of Newcastle, that 'the clansmen are divided among themselves, which is a consolation, but whether a common mischief might not bring them to unite I cannot answer.' Cameron narrowly escaped capture on one occasion, but the Jacobite warning system worked well enough to protect him. There were, however, too many Highlanders who, either to satisfy some personal feud or to improve their standing with the Government, would betray their countrymen. And, towards the end of 1752 Cameron had the ill luck to fall in with such a one when he was staying, 


\section{Lord Amulree}

disguised and under an assumed name, in a house on the banks of Loch Katrine, probably belonging to Stewart of Glenbuckie. He met with the informer, an old acquaintance, and told him that he was looking for a new lodging, for he intended to stay in Scotland till May or June, but if nothing happened by that time he would never credit any promise on behalf of the Pretender'. This information was at once passed to Whitehall and it was decided to search the house named in the report. There was a garrison in the Government barracks at Inversnaid on Loch Lomond about five miles away, and on 21 March a small party under Captain Craven set out on its mission. It was decided to go by road and not to cross the Loch in boats and Craven was careful that no one went ahead to give warning. This was wise 'for when we came within a mile and a half of the place the country people despatched a girl before us, whereupon I ordered one of the best marchers to pursue her, and to prevent her getting to the house before us. She however got before the soldier to a cabin about half way to Stewart's house and from thence despatched a boy whom the soldier likewise pursued and by presenting his piece and threatening to shoot him, brought him to a halt and prevented his getting on before us'. The boy was stopped about a quarter of a mile from Stewart's house, and before going any farther Craven divided his party into two groups of six who approached the house one from the back and one from the front. Cameron was seen to dash out into the woods, but was soon caught, brought back to the Captain and searched: nothing incriminating was found on him and he was marched back to Inversnaid, where the party arrived about two o'clock in the morning 'heartily tired having waded through rivers and bogs up to my knees, and passed some rough, rocky mountains, but the satisfaction of succeeding makes fatigue rather a pleasure.'

Cameron's name was included in the Act of Attainder which was passed in 1746 and was excluded from the Act of Indemnity passed in the following year. He would, therefore, have no chance of defending himself if he were to be found in Scotland by the British authorities and his sentence to death would certainly follow, unless the Government were to show unexpected signs of mercy. He was moved next day to Stirling Castle, where he was identified as the person mentioned in the Act of Attainder by two independent witnesses. On the next day Erskine examined him in Edinburgh Castle and reported that he seemed 'in great concern' but yet would give nothing away, maintaining that he had come to Scotland solely on private matters. Erskine warned him 'of the dangerous precipice on which he stood, if he did not by some very material discovery open a door to let in hopes of His Majesty's innate clemency'. Erskine wondered if he might be encouraged to say more if he were to be 'examined in more awful presence'. Newcastle agreed with this suggestion and on 4 April he was sent under strong escort, to London, where he arrived on 16 April, the anniversary of the battle of Culloden, and was confined in the Tower of London, probably in the Lieutenant's lodgings. As was the custom of the time, he, or his family, were expected to pay $£ 40 s$. $0 d$. a week for his own keep and for that of the two warders to whom his safety was assigned. The following day he was examined by the Privy Council. They, again, got no useful information out of him, but one curious brush with the Duke of Newcastle is recorded. On being asked why he took an expensive and long journey to Rome: 


\section{Dr. Archibald Cameron}

the Doctor honestly and plainly answered 'I went to see my old master, and to receive his commands for my young master'. 'And did you see your young master lately?' Answer 'yes'. 'Where did you see him?' Answer 'At Paris'. (Here a considerable pause was made, and orders were given to note down exactly the words of the Doctor, they imagining some mighty discovery to be made by him.) Then it was asked 'When did you see your young master (as you call him) last in Paris?' Answer 'in 1748.' They were much enraged at this answer, as they conjectured the doctor would have condescended upon some time later. viz in 1751 or 1752. The Duke of Newcastle, in particular, was so provoked that he stormed furiously and bawled out 'This is the height of insolence! most insufferable insolence! insolence not to be borne with! etc. etc.' In a word such was the blustering that Dr. Cameron (as he acknowledged to a particular friend) was almost ready to smile, even in the presence of the Council.

Further witnesses were found in London who could identify him and on the following day he was brought before the court of King's Bench and sentenced to death by hanging. He 'heard his sentence without any alteration of countenence, except that his lips closed and his mouth began to fill, and he made three or four very low reverences to the bench when he retired.' Execution was postponed till 7 June, so that Mrs. Cameron might come over from France to join him for a few days: she was then living at Lille. Cameron said that 'he had seven children who, with his wife, were all dependant upon him and his not seeing her would be worse for him than death'. The mixture of compassionate understanding and unyielding hardness shown by the authorities makes strange reading today.

News of Cameron's arrest soon spread in Jacobite circles, and attempts were made by the French government, by means of their ambassador in London, the Duc de Mirepoix, to ensure his release on the grounds that he was a serving officer in the forces of the Most Christian King as a colonel of the regiment of Albany and as a captain of the Foot. James wrote also to Cardinal Portocarrero requesting him to draw the attention of Carvajal to Cameron's danger and emphasizing that he was a colonel in the service of the Most Catholic King. Mrs. Cameron, too, tried her best to secure a reprieve, but all without success. She had arrived in London on 29 May and on 31 May was made a prisoner with her husband in the Tower. She left him in the evening of 6 June, when the gates of the Tower were locked, and at 10 o'clock on the following morning Cameron was moved, with an escort of soldiers, on to Tower Green, where he was handed over to the Sheriff: he was wearing a lightcoloured coat, red waist and breeches and a new bag-wig. He was then bound on a hurdle and drawn by four horses to the place of execution at Tyburn, where he arrived at quarter past twelve. After joining with the clergyman who accompanied him in the commendatory prayer Cameron said farewell to him and, as he seemed to stumble as he went down the steps from the cart, called after him in a cheerful voice 'Take care how you go, I think you don't know this way as well as I do'. He then made a present of money to the executioner and was immediately turned off. The body was allowed to hang on the gallows for three quarters of an hour and was then cut down. As it was not the Government's wish that his body should be dismembered after death it was handed over to an undertaker in the Strand and on the following day was buried in the chapel of the Savoy in the presence of four of his friends. Cameron was forty-six years of age at the time of his death.

The Government have been criticized for apparent harshness in executing Cameron on an old Act of Attainder. This is probably to be explained by the fact that there 


\section{Lord Amulree}

had been considerable underlying unrest in the Highlands since 1746 and this was encouraged by visits of Jacobites from Europe with messages from the Prince and others promising a new rising. Cameron was the first prominent person among these messengers to be caught and it was thought that to make an example of him then might scotch the whole movement. If this was the reasoning, it seems to have been justified, for there seems to have been little dangerous Jacobite activity in Scotland after his death.

\section{ACKNOWLEDGEMENT}

I have to acknowledge with grateful thanks the gracious permission of Her Majesty the Queen to make use of material in the Royal Archives at Windsor Castle.

\section{SELECTED BIBLIOGRAPHY}

Stuart Papers, Royal Archives, Windsor.

Ministère des Affaires Etrangers, Service des Archives: Paris.

Spanish state archives.

State Papers, Scotland: 54/42, 36, 43, 78, 121.

Cumberland papers.

Letter book of General Churchill.

British Museum: additional mss. 327, 371, 32, 732.

National Library of Scotland: 3187.

Letter book: Tower of London.

University of Edinburgh; Register of fees.

The Lyon in Mourning, 1895.

Browne, JAMrs, History of the Highland and the Highland Clans, 1840.

HENDERSON, ANDREW, Memoir of Dr. Archibald Cameron, brother to the famous Donald Cameron of Lochiel, 1753.

SALMOND, J. B. S., Wade in Scotland, 1934. 